\title{
The immunobiology of cholangiocytes
}

\author{
Xian-Ming Chen ${ }^{1}$, Steven P O'Hara ${ }^{2}$, and Nicholas F LaRusso ${ }^{2}$ \\ 1 Department of Medical Microbiology and Immunology, Creighton University Medical Center, Omaha, NE, \\ USA \\ 2Miles and Shirley Fiterman Center for Basic Research in Digestive Diseases, Division of Gastroenterology \\ and Hepatology, Mayo Clinic College of Medicine, Rochester, MN, USA
}

\begin{abstract}
Cholangiocytes, the epithelial cells lining bile ducts, provide the first line of defense against lumenal microbes in the biliary system. Recent advances in biliary immunity indicate that cholangiocytes express a variety of pathogen-recognition receptors and can activate a set of intracellular signaling cascades to initiate a profound antimicrobial defense, including release of proinflammatory cytokines and chemokines, production of antimicrobial peptides and maintenance of biliary epithelial integrity. Cholangiocytes also interact with other cell types in the liver (for example, lymphocytes and Kupffer cells) through expression and release of adhesion molecules and immune mediators. Subsequently, through an intricate feedback mechanism involving both epithelial and other liver cells, a set of intracellular signaling pathways are activated to regulate the functional state of cholangiocyte responses during microbial infection. Thus, cholangiocytes are actively involved in mucosal immunity of the biliary system and represent a fine-tuned, integral component of liver immunity.
\end{abstract}

\section{Keywords}

biliary epithelium; immunity; Toll-like receptors; microRNAs

The biliary tract comprises a complex 3-dimensional network of conduits lined by specialized secretory/excretory epithelial cells called cholangiocytes. Although human bile is sterile under normal conditions, the biliary tract exits into the duodenum, which is periodically colonized. Indeed, duodenal microorganisms are believed to be a major source of microbial infection in several hepatobiliary diseases. ${ }^{1-6}$ Conversely, the portal vein also constitutes an alternate source of infection for the biliary system. 7,8 To guard against the infection of pathogens, the biliary tract is equipped with several defense mechanisms. Cholangiocytes express a variety of pathogen pattern recognition receptors (for example, Toll-like receptors (TLRs)). ${ }^{6-11}$ Activation of pathogen pattern recognition receptor-associated intracellular signaling cascades result in the expression of several adhesion molecules, inflammatory mediators (for example, cytokines/chemokines) and antimicrobial peptides, initiating epithelial immune responses against microbial infection. ${ }^{6-13}$ Infection also induces signaling cascades required for maintenance of the integrity of the biliary epithelial barrier and cross-talk with other immune cells in the liver, ${ }^{12-15}$ indicating a key role for cholangiocytes in the defense response in the biliary tree.

As with other epithelial cells, the response of biliary epithelial cells to microbial insult must be stringently regulated as exaggerated expression of signaling components as well as

Correspondence: Dr X-M Chen, Department of Medical Microbiology and Immunology, Creighton University Medical Center, Criss II, Room 529, 2500 California Plaza, Omaha, NE 68178, USA. E-mail: xianmingchen@creighton.edu. 
proinflammatory cytokines can have devastating effects on the host. ${ }^{16,17}$ Nevertheless, cholangiocytes exhibit intricate feedback regulatory mechanisms to synchronize the positive activation and negative regulation of signal transduction to avert potentially harmful immunological consequences. ${ }^{11-13}$ This review summarizes the current understanding of cholangiocyte immunobiology, including various mechanisms employed by negative regulators to ensure the appropriate modulation of cholangiocyte immune responses against microbial infection, with a focus on TLR-associated biliary epithelial immunity.

\section{RECOGNITION OF PATHOGEN-ASSOCIATED MOLECULAR PATTERNS}

Several families of proteins are involved in recognition of pathogens and the products released from injured or dying cells. The best characterized of these receptors are TLRs and nucleotidebinding oligomerization domain proteins (NODs). ${ }^{18-20}$ Surprisingly, mRNAs for all 10 known human TLRs were detected in human cholangiocytes using an SV40 transformed cholangiocyte cell line. ${ }^{10}$ Expression of multiple TLR proteins in human cholangiocytes has been confirmed by several groups in human liver tissues by immunohistochemistry. ${ }^{9}$ Multiple TLRs have also been identified in murine cholangiocytes and several human cholangiocarcinoma cell lines. $., 21,22$ Expression of multiple TLRs by cholangiocytes may reflect the specific microenvironment and function of cholangiocytes in the biliary immunity. For example, intestinal epithelial cells at villus tips express very low levels of TLRs; ${ }^{23}$ therefore, the commensal bacteria do not induce inflammatory responses. However, the epithelial cells comprising intestinal crypts, which are not typically exposed to lumenal contents, express multiple TLRs at a higher level and are responsive to microbes (Figure 1a). 24,25 Similar to intestinal crypts, the biliary tract is typically sterile but connected and open to the intestinal tract (Figure 1b).

Activation of TLRs has been demonstrated in cholangiocytes during bacterial, viral and parasitic infection. $6,10,12,26-32$ In addition, several endogenous molecules have been reported to activate TLRs. ${ }^{19}$ Of those endogenous molecules, heat-shock proteins, fibronectin and hyaluronic acid can be found in the bile. ${ }^{1,33-35}$ Moreover, activation of TLRs by microbes in cholangiocytes may involve a rearrangement of the epithelial membrane surface including localized accumulation of membrane rafts. ${ }^{36}$ Cryptosporidium parvum (C. parvum) is a protozoan parasite that activates both TLR2 and TLR4 in cholangiocytes to initiate epithelial host responses. ${ }^{10,32,37}$ Infection of cultured human cholangiocytes by $C$. parvum recruits both TLR2 and TLR4 and ganglioside GM1, an important component of membrane rafts, to C. parvum infection sites. ${ }^{36}$ Moreover, membrane recruitment of ganglioside GM1 appears to be required for the subsequent activation of TLR-associated intracellular signals including the phosphoinositide-3 kinase (PI3K) and the extracellular signal-regulated kinases 1 (ERK1) and ERK2. ${ }^{36}$ Similarly, membrane rafts have been implicated in TLR activation in several other cell types, including epithelial cells, following microbial infection. 38,39

\section{ACTIVATION OF INTRACELLULAR SIGNALING CASCADES}

When TLRs or NODs are engaged by their ligands, various adaptor molecules are selectively recruited to the receptors forming a complex of receptors and adaptors, so called 'signalosome'. 18,40 Oligomerization and interactions of TLRs or NODs with adaptor molecules result in recruitment of 'downstream' signaling components to the receptor complex, thereby triggering downstream events. ${ }^{20,41,42}$ Whereas many downstream signaling pathways can be activated through TLRs and NODs, the nuclear-factor $\kappa \mathrm{B}(\mathrm{NF}-\mathrm{\kappa B})$ and mitogen-activated protein kinase (MAPK) pathways have been implicated as essential components of immune defense in cholangiocytes (Figure 2). 


\section{The NF-kB pathway}

The NF- $\mathrm{KB}$ proteins comprise a ubiquitously expressed transcription factor complex belonging to the Rel family of proteins. ${ }^{43,44}$ In most cells, NF- $\mathrm{KB}$ exists in a latent state in the cytoplasm bound to inhibitory $\mathrm{\kappa Bs}$ that mask its nuclear localization signal. Activation of NF- $\kappa \mathrm{B}$ causes it to move into the nucleus and regulate the expression of a number of host genes, the products of which activate mucosal inflammatory and immune responses and alter epithelial functions. 43,44 Recent studies reveal two pathways for the activation of NF- $\mathrm{kB}$ : an established (canonical) and an alternate (noncanonical) pathway (Figure 2). ${ }^{43,44}$

Activation of the NF- $\kappa B$ signal pathway through TLRs/NODs is a common response in many epithelial cells including cholangiocytes following microbial infection. ${ }^{9-11,32}$

Lipopolysaccharide (LPS), one of the most potent of the known bacterial agonists to TLR4, activates human cholangiocytes for synthesis of cytokines/chemokines such as tumor necrosis factor- $\alpha$ (TNF- $\alpha$ ) through a TLR4-MyD88-dependent pathway. ${ }^{9,22}$ Activation of NF- $\mathrm{KB}$ in cholangiocytes following $C$. parvum infection is dependent upon TLR2 and TLR4. ${ }^{10}$ Whereas several TLRs have been reported to act as receptors for microbial attachment in other epithelial cells, ${ }^{45}$ C. parvum attachment to and invasion of cultured cholangiocytes appear not to be dependent on host-cell TLRs. ${ }^{10}$

\section{The MAPK pathways}

The MAPK pathways transduce a large variety of external signals, leading to a wide range of cellular responses, including growth, differentiation, inflammation and apoptosis. Among the four wellestablished MAPK pathways (ERK, c-Jun N-terminal kinase (JNK), p38 and ERK5) in mammals, the MAPK/ERK, MAPK/JNK and MAPK/p38 pathways are closely linked with inflammation. ${ }^{46,47}$ Recent studies demonstrated the importance of MAPK activation in cytokine and chemokine gene expression in general, and provided many specific examples of genes that are regulated preferentially by one or the other MAPKs. ${ }^{48-50}$

The activator protein-1, which plays a critical role in inflammation and chronic inflammatory diseases, ${ }^{46,48}$ is an important transcription factor activated by the different MAPK pathways. For example, JNK phosphorylates and activates the activator protein-1 and activating transcription factor- 2 and other cellular factors linked to the regulation of altered expression of inflammation-associated genes including cytokines, cell surface receptors, cell adhesion molecules and matrix proteases. LPS activates innate immunity in cholangiocytes by producing interleukin (IL)-6 and IL-8 through the TLR4-NF- $\mathrm{kB}$ and TLR4-MAPK signaling pathways, 9 and in particular, LPS induced proliferative response of cholangiocytes is p44/p42 MAPK pathway-dependent. ${ }^{51}$ In addition, MAPK signaling contributes to rotaviral-induced cholangiocyte injury and viral replication. 52

\section{ACTIVATION OF CHOLANGIOCYTE IMMUNE RESPONSES}

Activation of intracellular signaling cascades through pathogen-recognition receptors will initiate a panel of epithelial immune responses in cholangiocytes. Release of proinflammatory cytokines/chemokines and expression of adhesion molecules in cholangiocytes will initiate an inflammatory response in the biliary tract and facilitate the cross-talk with other immune cells in the liver. Production of antimicrobial peptides can lead to a direct antimicrobial response in the biliary tree. In addition, evidences have accumulated that activation of associated intracellular signaling pathways in cholangiocytes is involved in the maintenance of epithelial barrier integrity. 


\section{Secretion of cytokines and chemokines}

Human cholangiocytes constitutively express and secrete IL-8 and monocyte chemotactic protein-1. ${ }^{53}$ Both IL-8 and monocyte chemotactic protein-1 are important chemotactic agents for neutrophils, monocytes and $\mathrm{T}$ cells. Importantly, a variety of cytokines and chemokines are produced and secreted from cholangiocytes under pathological conditions. ${ }^{12}$ In the course of liver injury, cholangiocytes secrete factors such as human growth factor, platelet-derived growth factor $\mathrm{BB}$, tumor growth factor- $\beta 2$, connective tissue growth factor and endothelin-1. ${ }^{54,55}$ TLR signaling pathway is involved in induced production of cytokines and chemokines in cholangiocytes. For example, LPS induces expression and secretion of IL-12 and TNF- $\alpha$ in immortalized mouse cholangiocytes from small intrahepatic ducts through activation of TLR4. ${ }^{12,22}$ Secretion of IL-8 from cultured human cholangiocytes following $C$. parvum infection is also dependent on TLR 2 and TLR4 on the cell surface and subsequent activation of NF-кB. ${ }^{10}$ Expression of cytokines and chemokines by cholangiocytes could result in the recruitment and activation of $\mathrm{T}$ cells, macrophages and natural killer cells to protect against biliary infection (for an extensive review, see Selmi et al. ${ }^{13}$ and Lazaridis et al. ${ }^{56}$ ).

\section{Expression of adhesion molecules}

The expression of adhesion molecules on the surface of cholangiocytes modulates their interaction with other cell types in the liver. Some cell surface adhesion molecules, such as leukocyte functioning antigen (LFA)-3, human leukocyte antigen (HLA)-I and HLA-II, are expressed in normal human cholangiocytes as demonstrated by both in vivo and in vitro studies. 57-59 Enhanced expression of adhesion molecules on cholangiocytes has been demonstrated in several inflammatory hepatobiliary diseases including primary biliary cirrhosis, primary sclerosing cholangitis and hepatolithiasis. ${ }^{60,61}$ Additionally, microbial infection in the biliary system is usually associated with an enhanced expression of adhesion molecules on cholangiocytes. Expression of HLA-I on cultured human cholangiocytes was increased after infection with the cytomegalovirus. ${ }^{58}$ Similarly, cholangiocytes isolated from extrahepatic bile ducts of $\mathrm{BALB} / \mathrm{c}$ mice constitutively expressed low levels of intercellular adhesion molecule-1, major histocompatibility (MHC) class I and MHC class II. Levels of MHC class I and class II expression were significantly enhanced by interferon- $\gamma$ (INF- $\gamma$ ) stimulation and following murine cytomegalovirus infection. ${ }^{62}$

Cholangiocytes express cell surface adhesion molecules to facilitate interactions with immune cells in the liver. Adhesion molecules expressed on the cholangiocyte surface permit the adhesion and recognition of lymphocytes and subsequently, the activation of cytotoxic effector lymphocytes. ${ }^{12}$ Thus, such interactions modulate the intensity and localization of the inflammatory reactions in the biliary system. ${ }^{12}$ For example, the presence of LFA-3 on the cell surface of cholangiocytes allows the interaction with CD2 molecules expressed on cytotoxic T lymphocytes and natural killer cells, leading to cell cytotoxicity. ${ }^{63} \mathrm{~T}$ cells can be activated by an alternative mechanism that involves CD40 expressed on cholangiocytes. ${ }^{59}$ Moreover, the CD40/CD40L and the LFA-2/LFA-3 system trigger the production of IL-12, which plays an important role in the cytotoxic response of cholangiocytes. CD40 and CD40L expression in cholangiocytes are increased, respectively, by stimulation with IFN- $\gamma$ and activation of LFA-2 on T cells. 59

\section{Function as antigen-presenting cells (APCs)}

Unlike other epithelial cell types, human cholangiocytes express MHC class II and possess the potential to act as APCs. ${ }^{59,64,65}$ This expression increases following cholangiocyte injury or stimulation with IFN- $\gamma$ and IL-1 ${ }^{64}$ However, efficient interactions between APCs and dendritic cells requires MHC class II in the presence of costimulatory molecules expressed on the APCs, such as the members of the B7 family, (that is, B7-1 (CD80) and B7-2 (CD86)), 17 which are not constitutively expressed by human cholangiocytes. ${ }^{63}$ Nevertheless, 
cholangiocytes normally express low levels of $\mathrm{B} 7$ family members (programmed death-ligand 1 (PD-L1) (B7-H1) and PD-L2 (B7-DC)) that interact with PD-1, a receptor expressed on activated T-cells. ${ }^{66}$ Expression of B7-H1 was also induced in cultured human cholangiocytes following the treatment with IFN- $\gamma$ and TNF- $\alpha$ (our unpublished data). Given the fact that the biliary epithelial barrier consists of a single, continuous layer of cholangiocytes, which differs from intestinal epithelia where other cell types (such as the Patch cells and M cells) are involved in antigen processing and presentation, it is plausible that cholangiocytes function as APCs for microbial infection in the biliary system.

As suggested in other tissues, macrophage phagocytosis of apoptotic cells containing the pathogens may contribute to antigen presentation. Apoptotic cell death of cholangiocytes during microbial infection has been reported both in vivo and in vitro. ${ }^{67-69}$ However, whether apoptotic cell death of cholangiocytes is involved in the antigen presenting process is unclear. In particular, cholangiocytes that undergo apoptosis may not directly infected. C. parvuminduced apoptosis in cholangiocytes is limited to bystander noninfected cells through a Fas/ FasL-dependent mechanism. ${ }^{70}$

\section{Production and secretion of antimicrobial molecules}

Human $\boldsymbol{\beta}$-defensins (hBDs)—Defensins are small (2-6 kDa) cationic peptides with antimicrobial activity that kill pathogens through membrane disruption. Defensins are divided into two major groups, $\alpha$-defensins and $\beta$-defensins, based on their structure. ${ }^{71} \alpha$-Defensins are particularly abundant in neutrophils and Paneth cells of the small intestine. ${ }^{71}$ Of the six $\beta$-defensins (hBD-1 to hBD-6) that have been identified in humans, ${ }^{71,72} \mathrm{hBD}-1$ is constitutively expressed, whereas hBD-2 and hBD-3 are inducible by bacterial and viral products and cytokines. hBD- 4 has a more limited distribution than hBD-1, hBD-2 or hBD-3 and its expression can be upregulated by bacterial infection, but not by inflammatory factors. hBD- 5 and hBD- 6 are localized to the epididymis and airways. ${ }^{71}$ Thus, hBDs play a crucial role in host defense against bacterial infection as constitutive or inducible components in the epithelial barrier.

In a study to investigate the expression of hBD- 1 and hBD-2 in cultured human cholangiocytes and in cholangiocytes in specimens of human liver including those with primary biliary cirrhosis, primary sclerosing cholangitis or chronic hepatitis $\mathrm{C}, \mathrm{hBD}-1$ protein was detected in hepatocytes and cholangiocytes of intrahepatic bile ducts in all of the specimens of liver tissues. 6 hBD-1 protein was also identified in the bile of both normal subjects and those with the diseases, ${ }^{6}$ suggesting that hBD-1 plays a general antimicrobial role in the defense of the hepatobiliary system, similar to that documented in other epithelial organs. In contrast, hBD-2 was not detectable in cholangiocytes or hepatocytes from normal subjects. However, expression of hBD-2 was identified in the large bile ducts exhibiting features of cholangitis in patients with hepatolithiasis. Expression of hBD1-3 has further been confirmed in a SV40 transformed human cholangiocyte cell line. ${ }^{10}$ Whereas hBD1-3 were detected at the message level in the cell line, upregulation of hBD-2, but not hBD-1 and hBD-3, was demonstrated in a TLR2/TLR4-dependent manner in cells following C. parvum infection. ${ }^{10}$ Thus, it appears that both hBD-1 and hBD-3 may play a general antimicrobial role in the defense of the biliary system, similar to that documented in other epithelia. ${ }^{73}$ In contrast, TLR-induced expression of hBD-2 may provide epithelial cells (for example, cholangiocytes) a critical local defense response against microbial infection.

Mx proteins-Mx proteins are key components of antiviral immunity induced by IFNs in many species. They belong to the class of dynamin-like large guanosine triphosphatases (GTPases) known to be involved in intracellular vesicle trafficking and organelle homeostasis. A unique property of some Mx GTPases is their antiviral activity against a wide range of RNA 
viruses, including influenza viruses and members of the bunyavirus family. Mx GTPases appear to detect viral infection by sensing nucleocapsid-like structures. As a consequence, these viral components are trapped and sorted to locations where they become unavailable for the generation of new virus particles. ${ }^{74}$

Whereas emphasis has been on the expression of Mx proteins in Kupffer cells, lymphocytes and hepatocytes, recent studies revealed that cholangiocytes also express Mx proteins under pathological conditions. In normal human liver tissues, only small numbers of Kupffer cells, but not hepatocytes and cholangiocytes, exhibited MxA expression. In contrast, strong expression of MxA protein was identified in Kupffer cells and cholangiocytes in patients with chronic liver diseases and fulminant hepatic failure. ${ }^{75}$ As in other cell types, expression of MxA protein in cholangiocytes is associated with IFNs. Indeed, in most cases, the MxApositive cholangiocytes in patients with chronic liver diseases and fulminant hepatic failure also exhibited increased expression of IFNs. More recently, a role for TLRs and IFN signaling in induced MxA protein expression in cholangiocytes has been demonstrated both in vivo and in vitro models of biliary infection. A significant increase of TLR7 and MxA, both at mRNA and protein levels, was found in patients in early stage of biliary atresia compared with control subjects. ${ }^{76,77}$ Infections with Reoviridae, a family of viruses with a double-stranded RNA (dsRNA) genome, known to infect the gastrointestinal and respiratory system, are a possible cause of biliary atresia. Stimulation of cultured human cholangiocytes with polyinosinicpolycytidylic acid (poly(I:C)), a synthetic analog of viral dsRNA and a ligand for TLR3, induced a potent antiviral response with increased production of interferon- $\beta 1$ and MxA. ${ }^{78}$

Secretory immunoglobulin A (slgA)-Secretory immunoglobulin A is the characteristic and predominant immunoglobulin of the mucosal immune system and it participates in immunological protection at the level of mucous membrane surfaces. The predominant immunoglobulin in bile is sIgA, although $\operatorname{IgM}$ and $\operatorname{IgG}$ do exist in bile but in a much lower levels. Transportation of sIgA into the biliary tract is an active receptor-mediated process through the secretory component. In some animals (rats, mice and rabbits), the secretory component is synthesized and expressed on the sinusoidal surface of the hepatocytes and sIgA is transported to bile canaliculi through hepatocytes. In other animals (dog, guinea and sheep), as well as in humans, the secretory component is not expressed in hepatocytes, instead, it is a process associated with cholangiocytes. ${ }^{79}$

Transport of sIgA through cholangiocytes into bile is an important component of biliary mucosal immunity in humans. ${ }^{12}$ IgAs could be a protective factor for bile ducts by preventing the attachment of pathogens or their toxins to the surface of cholangiocytes. ${ }^{1}$ Studies have shown that natural $\operatorname{IgA}$ antibodies against a variety of intestinal bacteria are present in bile, and after inoculation of various antigens into the intestinal lumen or intestinal lymphoid tissues, a consequent secretion of specific IgA antibodies that protect from biliary tract infections is evident in the bile of experimental animals. ${ }^{80}$ This function of IgAs could be ascribed to their capacity to form immune complexes with circulating antigens, reducing the systemic response caused by pathogens present in systemic circulation and preventing chronic inflammation derived from antigens continuously present in the gastrointestinal mucosa. IgA has also been implicated in binding intracellular pathogens during the transcytosis process into cholangiocytes. 81

\section{Maintenance of biliary epithelial barrier integrity}

Cholangiocyte proliferation-Proliferation is a 'typical' property of cholangiocytes and is a key mechanism of repair responsible for maintaining the integrity of the biliary tree. Cholangiocyte proliferation occurs virtually in all pathologic conditions of liver injury where 
it is associated with inflammation, regeneration and repair, thus conditioning the evolution of liver damage. 82

Recent evidence supports a role for the TLR-MyD88-mediated signaling in the regulation of epithelial homeostasis under steady-state conditions and for the expression of protective molecules in epithelial cells following mucosal injury. ${ }^{83}$ Indeed, Staphylococcus aureus $(S$. aureus) and microbial patterns signaling through TLR2 and TLR5 induce a set of noninflammatory epithelial responses in human airway epithelial cells including cell migration, wound repair, proliferation and survival of primary and cancerous epithelial cells. Using small interfering RNA (siRNA) gene targeting, it has been shown that activation of epidermal growth factor receptor (EGFR) through TLR2/TLR5 signaling mediates the stimulating effect of microbes on epithelial proliferation. ${ }^{84}$ Stimulation of epithelial TLRs induces activation of a panel of receptors with tyrosine kinase activity. Notably, all four members of the EGFR family including EGFR (ErbB-1), HER2/c-neu (ErbB-2), Her 3 (ErbB-3) and Her 4 (ErbB-4)

displayed an increase of phosphorylation. The NOD proteins that recognize microbial patterns in the cytosol and endosomal TLRs do not exert such effects. ${ }^{84}$ Thus, it appears that there is a direct link between TLR-mediated recognition of microbes by epithelial cells and epithelial homeostasis. This mechanism that operates independently of inflammatory cells and cytokines, involves activation of EGFR, is likely involved in regulation of epithelial integrity under steady-state conditions as well as during infection, including microbial infection in the biliary system. 84

Trefoil factors (TFFs) and biliary mucosal repair-TFFs, including TFF1, TFF2 and TFF3 are mucin-associated proteins involved in the maintenance of mucosal barrier and restitution of a contiguous layer of epithelial cells. TFFs are integral to cytoprotection and cellular repair of the mucosa, involved in the maintenance of mucosal barrier and the biological behavior of epithelial and carcinoma cells. Each of the TFF proteins is differentially regulated in different parts of the gastro-intestinal tract. ${ }^{85,86}$ TFF1 and TFF2 are expressed primarily in the stomach and TFF3 predominates in the small and large intestines. ${ }^{87}$

Cholangiocytes in normal human liver tissue express TFFs, particularly in the larger bile ducts. TFF1 and TFF3 are constitutively expressed in the large bile ducts of mouse and human livers. 14,87-89 TFF expression may be upregulated or induced in biliary diseases as a response to injury, as is seen in epithelial damage elsewhere in the gastrointestinal tract. ${ }^{89}$ Indeed, expression of TFF1, TFF2 and TFF3 were augmented markedly in biliary mucosa in hepatolithiasis. TFF3 was detected in hepatic bile samples of hepatolithiasis. 90 Expression of TFF1-3 was also examined by immunohistochemistry in primary biliary cirrhosis, primary sclerosing cholangitis, chronic viral hepatitis, extrahepatic biliary obstruction and normal livers. The intrahepatic biliary tree showed a site-characteristic expression and induction of TFFs. In large bile ducts, TFF1 and TFF3 were constitutively expressed and were increased in pathologic bile ducts. In small bile ducts, TFF2 was induced in damaged ducts irrespective of etiologies. 14

Tight junctions and maintenance of the biliary epithelial barrier-Similar to that in the intestinal and renal tubular epithelia, the tight junctions in biliary epithelia are formed by the organization of a number of specific proteins including occludin, zonula occludens (ZO-1, $\mathrm{ZO}-2, \mathrm{ZO}-3)$, claudins and junctional adhesion molecule, ${ }^{91}$ providing barrier function to the biliary epithelium. The tight junction proteins interact with the perijunctional actomyosin ring. Additionally, a variety of intracellular signaling molecules such as c-Src, phosphatidylinositol 3-kinase, ERK, protein kinase $\mathrm{C}$ and protein phosphatase $2 \mathrm{~A}$ are localized at the tight junctions. 91,92 The tight junction and paracellular permeability are regulated by signaling molecules, such as intracellular calcium, cyclic AMP, GTPase switch protein and protein kinases. 15 
TLR signals can modulate cholangiocyte tight junction functions through activation of various intracellular signal pathways, similar to the epithelium in the respiratory and intestinal systems. However, the relationship between activation of TLR signals and disruption of tight junctions in cholangiocyte epithelial barrier during microbial infection is still quite controversial. TLR2 has been reported to enhance ZO-1-associated intestinal epithelial barrier integrity through protein kinase C. ${ }^{93}$ As for cholangiocytes, LPS, a potent activator for TLR4, disrupted the tight junctions and increased the paracellular permeability in cultured rat cholangiocyte monolayers in a dose-dependent manner. LPS-induced disruption of tight junctions in cholangiocyte monolayers was mediated by TLR4 through activation of the tyrosine kinase, $\mathrm{c}$-Src. ${ }^{15}$ Indeed, a decrease of transcellular electric resistance and activation of c-Src have also been described in cultured human cholangiocyte monolayers following infection by $C$. parvum $, 67,94$ a parasite that activates both TLR2 and TLR4 in cholangiocytes. ${ }^{10}$ Given the fact that multiple downstream signaling pathways can be activated through TLRs and many intracellular signals are involved in the functional regulation of tight junctions, it should not be a surprise that TLR activation on epithelial tight junctions differs in each epithelial cell type.

\section{REGULATION OF CHOLANGIOCYTE IMMUNE RESPONSES}

A well-orchestrated cholangiocyte immune response is essential to maintain mucosal homeostasis in the biliary tract. While cholangiocytes also interact with other cell types in the liver (for example, lymphocytes and Kupffer cells) through expression/release of adhesion molecules and immune mediators and play an active role in activation of both the innate and adaptive immunity compartment in the liver, cholangiocytes are also the target of other liver cells through release of immunoregulatory molecules or direct cell-cell interactions. At the cellular level, the intensity and duration of TLR responses in cholangiocytes are tightly controlled. Activation of TLRs can activate several endogenous feedback regulatory pathways to counter regulate TLR signaling cascades and promote resolution of inflammation. ${ }^{18}$

\section{Influence of cholangiocyte responses by other liver cells}

Cholangiocytes constitutively express several receptors for cytokines and chemokines including IL-4, IL-5, IL-6, IFN- $\gamma$ and TNF- $\alpha .{ }^{11,12}$ Therefore, cytokines and chemokines released from other liver cells can act on cholangiocytes and modulate cholangiocyte immune responses. Those inflammatory cytokines and chemokines mediate many of the cellular events in cholangiocytes including but not limited to epithelial immune responses, such as proliferation, secretion, apoptosis, cytotoxicity and expression of adhesion molecules. ${ }^{12,51 \text {, }}$ 95-97 Indeed, expression of adhesion molecules, such as intercellular adhesion molecule-1, MHC class I and class II, LFA-3, CD40 and CD95 are expressed in a cytokine-dependent fashion, mediated primarily by TNF- $\alpha$, IFN- $\gamma$, IL- 1 and tumor growth factor- $\beta .12$ A significant increase of intercellular adhesion molecule-1, HLA-I and HLA-II expression in cholangiocytes was also evident after stimulation with TNF- $\alpha$, IFN- $\gamma$ and IL- $1 .{ }^{64}$ Conversely, tumor growth factor- $\beta$ decreased the expression of these molecules but upregulated LFA-3. ${ }^{59}$ Consequently, those adhesion expressed on cholangiocytes mediate direct cell-cell interactions with other liver cells, in particular, lymphocytes. Although the effects of this direct cell-cell interaction on the local immune responses by cholangiocytes are still unclear, from a pathological view point, targeting of cholangiocytes by immune cells has been implicated in the pathogenesis of various hepatibiliary diseases, including primary biliary cirrhosis, primary sclerosing cholangitis and graft-verses-host liver disease. ${ }^{11-13}$

\section{Regulation of TLR expression}

Epithelial expression of TLRs is highly regulated, reflecting the specific microenvironment and function of each epithelial cell type. This specificity is critically important to assure that an epithelium will recognize invading pathogens but not elicit an intense immune responses 
to endogenous ligands or commensal microorganisms. ${ }^{19-23}$ Similar to other epithelial cells upon microbial infection in the intestinal and the respiratory system, 19,23,24,98,99 cholangiocytes usually display an upregulation of TLRs, potentially resulting in enhanced epithelial innate immunity. Indeed, infection of cultured human cholangiocytes by $C$. parvum induced a significant increase of TLR4 protein, a process that appears to be associated with the production of hBD2. Upregulation of TLRs in cholangiocytes has also been confirmed in patients with primary biliary cirrhosis, primary sclerosing cholangitis and hepatolithiasis. 100,101

Small regulatory RNAs, such as microRNAs (miRNAs), contribute to microbe-induced TLR expression in epithelial cells, including cholangiocytes. miRNAs are a newly identified class of endogenous small regulatory RNAs of 21-23 nucleotides. ${ }^{102}$ These molecules target messenger RNAs leading to post-transcriptional repression through either mRNA cleavage or translational suppression. ${ }^{102,103}$ It has become clear that miRNAs have diverse expression patterns and play essential roles in biological processes that include development, maintenance of genome stability and regulation of the immune system. ${ }^{104-109}$ Human cholangiocytes express a profile of endogenous miRNAs. ${ }^{32,110}$ Using an in vitro model of human biliary cryptosporidiosis, it has been reported that let-7 regulates TLR4 expression through posttranscriptional suppression in cultured human cholangiocytes. ${ }^{32}$ Infection of cultured human cholangiocytes with $C$. parvum, a parasite that causes intestinal and biliary disease, resulted in decreased expression of primary let-7i and mature let-7i in a MyD88/NF-B-dependant manner. The decreased let-7 expression was associated with C. parvum-induced upregulation of TLR4 in infected cells. ${ }^{32}$ Thus, let-7i regulates TLR4 expression in cholangiocytes and contributes to epithelial immune responses against $C$. Parvum infection (Figure 3).

\section{Negative regulation of TLR-associated signaling cascades}

To carry out a fine-tuning of TLR-associated immune responses, cells have also developed multiple strategies for negative regulation of TLR signaling that initiate events leading to resolution of the inflammatory responses. These strategies include the release of extracellular soluble decoy TLRs (for example, sTLR2 and sTLR4), interference of ligand-receptor interaction through transmembrane negative regulators, and activation of intracellular antagonists or signalings to downregulate TLR signaling. Many of those antagonists and negative regulators are ubiquitously expressed in mammal cells and have well-documented functions in many cell types (for an extensive review, see Lang and Mansel1 ${ }^{111}$ and Han and Ulevitch $^{18}$ ). Nevertheless, a function for some of these negative regulators has recently been elucidated in human cholangiocytes.

Expression of IL-1R-associated kinase-M (IRAK-M) and Tollip in human cholangiocytes has been described in a recent report by Harada et al. ${ }^{28}$ Whereas a low level of expression of both IRAK-M and Tollip was detected in cultured human cholangiocytes, treatment with LPS upregulated expression of IRAK-M. Upregulation of IRAK-M was demonstrated to be associated with the development of endotoxin tolerance in cholangiocytes. Furthermore, using human liver tissue sections demonstrating normal histology, it was confirmed that IRAK-M is expressed in vivo. This study demonstrated endotoxin tolerance in the intrahepatic biliary epithelium and suggests that the expression of IRAK-M is crucial to LPS-induced tolerance in biliary epithelial cells. It is speculated that endotoxin tolerance is important in maintaining innate immune biliary homeostasis and also that an impaired tolerance to LPS is associated with the pathogenesis of biliary diseases. 28

The cytokine-inducible Src homology 2 protein and suppressors of cytokine signaling (CIS/ SOCS) are a family of intracellular proteins, which have emerged as key physiological regulators of cytokine responses, including those that regulate inflammation. ${ }^{112-115} \mathrm{~A}$ wealth of evidence suggests that CIS/SOCS proteins function in a classical, negative-feedback loop 
inhibiting cytokine signal transduction and are essential for the termination of inflammation. 116 Nevertheless, recent studies demonstrated that CIS/SOCS may also involved in the feedback regulation of TLR signalings. The adaptor protein Mal is specifically involved in signaling through TLR2 and TLR4. Following TLR2 and TLR4 stimulation, Mal becomes phosphorylated by Bruton's tyrosine kinase and then interacts with SOCS1, which results in Mal polyubiquitination and subsequent degradation. ${ }^{115}$ SOCS3 has been proposed to act as a pivotal negative regulator of the IL-6/STAT-3 pathway in cholangiocytes. ${ }^{117}$ Thus, expression of other CIS/SOCS proteins and their role in regulation of cholangiocyte immune responses merits further study.

miRNAs may also contribute to negative regulation of TLR signaling in cholangiocytes. Recently, three miRNAs (miR-146, miR-132 and miR-155) have been identified that are sharply upregulated in response to LPS in human monocytic cells. ${ }^{118,119}$ A detailed survey of miR-146 expression in response to various microbial components revealed that an increase in miR-146 levels is induced by activation of the TLR/NF- $\kappa$ B pathway. Two predicted targets IRAK-1 and TNFR-associated factor 6 (TRAF6), whose involvement in TLR and proinflammatory cytokine (that is, IL-1) signaling is well established, have extensive sequence complimentarity to miR-146. Both molecules can potentially be the subjects of regulation by miR-146 resulting in a downregulation of IRAK-1 or TRAF6. ${ }^{119}$ Thus, miR-146b can serve as a regulator of TLR and cytokine signaling by acting in a negative feedback loop to attenuate activation of downstream genes through post-transcriptional regulation of expression of the IRAK-1 and TRAF6 proteins (Figure 3). ${ }^{109}$ Expression of miR-146 has been reported in human cholangiocytes 32,110 and whether miR-146 can target IRAK-1 or TRAF6 to regulate TLR signaling needs further investigation.

\section{CONCLUSION AND PERSPECTIVES}

Although progress has been made in defining mechanisms that enable cholangiocytes to display highly regulated immune responses against microbial infection in the biliary system, considerable gaps still exist in our knowledge. It appears human cholangiocytes express most types of TLRs, whereas other epithelial cells express limited number of TLRs. How cholangiocytes orchestrate signals from those TLRs to initiate an immediate immune response against microbial infection while attenuating excessive immune responses becomes key to understanding biliary mucosal homeostasis. The activation of inhibitory molecules and expression of miRNAs are likely involved in the regulation of the inflammatory response within the biliary system and merits further investigation. miRNAs are a potent and novel means to regulate gene expression and identification of miRNAs involved in the cholangiocyte innate immune response, targets of those miRNAs and physiological consequences of miRNAdependent gene silencing of critical proteins involved in this process will certainly be an active area of research. Our understanding of cholangiocyte immunobiology will be greatly enhanced through further investigations into the innate immune capacity of this epithelium and the intricate regulatory mechanisms controlling cholangiocyte-associated inflammatory processes.

\section{ACKNOWLEDGEMENTS}

We apologize to authors whose work could not be cited due to space limitations. Work in the authors' laboratory is supported by NIH Grant R01 AI071321 and the Tobacco Settlement Foundation of Nebraska LB 692 (to X-M Chen), NIH Grants R01 DK057993 (to NF LaRusso) and K01 DK076922 (to SP O’Hara).

\section{References}

1. Adams DH, Afford SC. The role of cholangiocytes in the development of chronic inflammatory liver disease. Front Biosci 2002;7:e276-e285. [PubMed: 12086915] 
2. Sheen-Chen S, Chen W, Eng H, Sheen C, Chou F, Cheng Y, et al. Bacteriology and antimicrobial choice in hepatolithiasis. Am J Infect Control 2000;28:298-301. [PubMed: 10926707]

3. Hiramatsu K, Harada K, Tsuneyama K, Sasaki M, Fujita S, Hashimoto T, et al. Amplification and sequence analysis of partial bacterial $16 \mathrm{~S}$ ribosomal RNA gene in gallbladder bile from patients with primary biliary cirrhosis. J Hepatol 2000;33:9-18. [PubMed: 10905580]

4. Sasatomi K, Noguchi K, Sakisaka S, Sata M, Tanikawa K. Abnormal accumulation of endotoxin in biliary epithelial cells in primary biliary cirrhosis and primary sclerosing cholangitis. J Hepatol 1998;29:409-416. [PubMed: 9764987]

5. Harada K, Ozaki S, Kono N, Tsuneyama K, Katayanagi K, Hiramatsu K, et al. Frequent molecular identification of Campylobacter but not Helicobacter genus in bile and biliary epithelium in hepatolithiasis. J Pathol 2001;193:218-223. [PubMed: 11180169]

6. Harada K, Ohba K, Ozaki S, Isse K, Hirayama T, Wada A, et al. Peptide antibiotic human betadefensin- 1 and -2 contribute to antimicrobial defense of the intrahepatic biliary tree. Hepatology 2004;40:925-932. [PubMed: 15382127]

7. Vaishnavi C, Kochhar R, Kaur S, Singh G. Estimation of endotoxin in infected bile from patients with biliary diseases. Trop Gastroenterol 2006;27:22-25. [PubMed: 16910056]

8. Yanaga K, Yoshizumi T, Uchiyama H, Okano S, Takenaka K, Sugimachi K. Detection of hepatitis C virus RNA in bile. Am J Gastroenterol 1997;92:1927-1928. [PubMed: 9382069]

9. Yokoyama T, Komori A, Nakamura M, Takii Y, Kamihira T, Shimoda S, et al. Human intrahepatic biliary epithelial cells function in innate immunity by producing IL-6 and IL-8 via the TLR4-NFkappaB and -MAPK signaling pathways. Liver Int 2006;26:467-476. [PubMed: 16629651]

10. Chen XM, O’Hara SP, Nelson JB, Splinter PL, Small AJ, Tietz PS, et al. Multiple TLRs are expressed in human cholangiocytes and mediate host epithelial defense responses to Cryptosporidium parvum via activation of NF-kappaB. J Immunol 2005;175:7447-7456. [PubMed: 16301652]

11. Harada K, Nakanuma Y. Biliary innate immunity and cholangiopathy. Hepatol Res 2007;37:S430S437. [PubMed: 17931198]

12. Fava G, Glaser S, Francis H, Alpini G. The immunophysiology of biliary epithelium. Semin Liver Dis 2005;25:251-264. [PubMed: 16143942]

13. Selmi C, Mackay IR, Gershwin ME. The immunological milieu of the liver. Semin Liver Dis 2007;27:129-139. [PubMed: 17520513]

14. Sasaki M, Tsuneyama K, Saito T, Kataoka H, Mollenhauer J, Poustka A, et al. Sitecharacteristic expression and induction of trefoil factor family 1, 2 and 3 and malignant brain tumor- 1 in normal and diseased intrahepatic bile ducts relates to biliary pathophysiology. Liver Int 2004;24:29-37. [PubMed: 15101998]

15. Sheth P, Delos Santos N, Seth A, LaRusso NF, Rao RK. Lipopolysaccharide disrupts tight junctions in cholangiocyte monolayers by a c-Src-, TLR4-, and LBP-dependent mechanism. Am J Physiol Gastrointest Liver Physiol 2007;293:G308-G318. [PubMed: 17446308]

16. Karin M, Lawrence T, Nizet V. Innate immunity gone awry: linking microbial infections to chronic inflammation and cancer. Cell 2006;124:823-835. [PubMed: 16497591]

17. Dong H, Chen XM. Immunoregulatory role of B7-H1 in chronicity of inflammatory responses. Cell Mol Immunol 2006;3:179-187. [PubMed: 16893498]

18. Han J, Ulevitch RJ. Limiting inflammatory responses during activation of innate immunity. Nat Immunol 2005;6:1198-1205. [PubMed: 16369559]

19. Akira S, Takeda K. Toll-like receptor signalling. Nat Rev Immunol 2004;4:499-511. [PubMed: 15229469]

20. Viala J, Sansonetti P, Philpott DJ. Nods and 'intracellular' innate immunity. C R Biol 2004;327:551555. [PubMed: 15330254]

21. Jo YJ, Choi HS, No NY, Lee OY, Han DS, Hahm JS, et al. Expression of Toll-like receptor in the biliary epithelial cell lines and human gallbladder tissues. Gastroenterology 2004;126:A171.

22. Harada K, Ohira S, Isse K, Ozaki S, Zen Y, Sato Y, et al. Lipopolysaccharide activates nuclear factorkappaB through toll-like receptors and related molecules in cultured biliary epithelial cells. Lab Invest 2003;83:1657-1667. [PubMed: 14615419]

23. Melmed G, Thomas LS, Lee N, Tesfay SY, Lukasek K, Michelsen KS, et al. Human intestinal epithelial cells are broadly unresponsive to Toll-like receptor 2-dependent bacterial ligands: 
implications for host-microbial interactions in the gut. J Immunol 2003;170:1406-1415. [PubMed: 12538701]

24. Sansonetti PJ. War and peace at mucosal surfaces. Nat Rev Immunol 2004;4:953-964. [PubMed: 15573130]

25. Shibolet O, Podolsky DK. TLRs in the Gut. IV. Negative regulation of Toll-like receptors and intestinal homeostasis: addition by subtraction. Am J Physiol Gastrointest Liver Physiol 2007;292:G1469-G1473. [PubMed: 17554134]

26. Miyaso H, Morimoto Y, Ozaki M, Haga S, Shinoura S, Choda Y, et al. Obstructive jaundice increases sensitivity to lipopolysaccharide via TLR4 upregulation: possible involvement in gut-derived hepatocyte growth factor-protection of hepatocytes. J Gastroenterol Hepatol 2005;20:1859-1866. [PubMed: 16336445]

27. Harada K, Isse K, Nakanuma Y. Interferon gamma accelerates NF-kappaB activation of biliary epithelial cells induced by Toll-like receptor and ligand interaction. J Clin Pathol 2006;59:184-190. [PubMed: 16443736]

28. Harada K, Isse K, Sato Y, Ozaki S, Nakanuma Y. Endotoxin tolerance in human intrahepatic biliary epithelial cells is induced by upregulation of IRAK-M. Liver Int 2006;26:935-942. [PubMed: 16953833]

29. Huang YH, Chou MH, Du YY, Huang CC, Wu CL, Chen CL, et al. Expression of toll-like receptors and type 1 interferon specific protein MxA in biliary atresia. Lab Invest 2007;87:66-74. [PubMed: 17075576]

30. Karrar A, Broomé U, Södergren T, Jaksch M, Bergquist A, Björnstedt M, et al. Biliary epithelial cell antibodies link adaptive and innate immune responses in primary sclerosing cholangitis. Gastroenterology 2007;132:1504-1514. [PubMed: 17408653]

31. Ikeda H, Sasaki M, Ishikawa A, Sato Y, Harada K, Zen Y, et al. Interaction of Toll-like receptors with bacterial components induces expression of CDX2 and MUC2 in rat biliary epithelium in vivo and in culture. Lab Invest 2007;87:559-571. [PubMed: 17417665]

32. Chen XM, Splinter PL, O'Hara SP, LaRusso NF́. A cellular micro-RNA, let-7i, regulates Toll-like receptor 4 expression and contributes to cholangiocyte immune responses against Cryptosporidium parvum infection. J Biol Chem 2007;282:28929-28938. [PubMed: 17660297]

33. Broomé U, Scheynius A, Hultcrantz R. Induced expression of heat-shock protein on biliary epithelium in patients with primary sclerosing cholangitis and primary biliary cirrhosis. Hepatology 2005;18:298-303. [PubMed: 8340058]

34. Sakisaka S, Koga H, Sasatomi K, Ohishi M, Kawaguchi T, Harada M, et al. Ursodeoxycholic acid reduces expression of heat shock proteins in primary biliary cirrhosis. Liver 2000;20:78-87. [PubMed: 10726964]

35. Körner T, Kropf J, Hackler R, Brenzel A, Gressner AM. Fibronectin in human bile fluid for diagnosis of malignant biliary diseases. Hepatology 2003;23:423-428. [PubMed: 8617420]

36. Nelson JB, O'Hara SP, Small AJ, Tietz PS, Choudhury AK, Pagano RE, et al. Cryptosporidium parvum infects human cholangiocytes via sphingolipid-enriched membrane microdomains. Cell Microbiol 2006;8:1932-1945. [PubMed: 16848787]

37. Rogers KA, Rogers AB, Leav BA, Sanchez A, Vannier E, Uematsu S, et al. MyD88-dependent pathways mediate resistance to Cryptosporidium parvum infection in mice. Infect Immun 2006;74:549-556. [PubMed: 16369011]

38. Hornef MW, Normark BH, Vandewalle A, Normark S. Intracellular recognition of lipopolysaccharide by toll-like receptor 4 in intestinal epithelial cells. J Exp Med 2003;198:1225-1235. [PubMed: 14568981]

39. Sorice M, Longo A, Capozzi A, Garofalo T, Misasi R, Alessandri C, et al. Anti-beta2-glycoprotein I antibodies induce monocyte release of tumor necrosis factor alpha and tissue factor by signal transduction pathways involving lipid rafts. Arthritis Rheum 2007;56:2687-2697. [PubMed: 17665396]

40. Beutler B, Hoebe K, Georgel P, Tabeta K, Du X. Genetic analysis of innate immunity: identification and function of the TIR adapter proteins. Adv Exp Med Biol 2005;560:29-39. [PubMed: 15934170] 
41. Kobayashi K, Inohara N, Hernandez LD, Galán JE, Núñez G, Janeway CA, et al. RICK/Rip2/ CARDIAK mediates signalling for receptors of the innate and adaptive immune systems. Nature 2002;416:194-199. [PubMed: 11894098]

42. Hasegawa M, Fujimoto Y, Lucas PC, Nakano H, Fukase K, Núñez G, et al. A critical role of RICK/ RIP2 polyubiquitination in Nod-induced NF-kappaB activation. EMBO J 2008;27:373-383. [PubMed: 18079694]

43. Hayden MS, Ghosh S. Chared principles in NF-кB signaling. Cell 2008;132:344-362. [PubMed: 18267068]

44. Pomerantz JL, Baltimore D. Two pathways to NF-kappaB. Mol Cell 2002;10:693-695. [PubMed: 12419209]

45. Frendéus B, Wachtler C, Hedlund M, Fischer H, Samuelsson P, Svensson M, et al. Escherichia coli P fimbriae utilize the Toll-like receptor 4 pathway for cell activation. Mol Microbiol 2001;40:3751. [PubMed: 11298274]

46. Whitmarsh AJ, Davis RJ. Transcription factor AP-1 regulation by mitogen-activated protein kinase signal transduction pathways. J Mol Med 1996;74:589-607. [PubMed: 8912180]

47. Katsoulidis E, Li Y, Mears H, Platanias LC. The p38 mitogen-activated protein kinase pathway in interferon signal transduction. J Interferon Cytokine Res 2005;25:749-756. [PubMed: 16375603]

48. Pimienta G, Pascual J. Canonical and alternative MAPK signaling. Cell Cycle 2007;6:2628-2632. [PubMed: 17957138]

49. Lang R, Hammer M, Mages J. DUSP meet immunology: dual specificity MAPK phosphatases in control of the inflammatory response. J Immunol 2006;177:7497-7504. [PubMed: 17114416]

50. Froy O. Regulation of mammalian defensin expression by Toll-like receptor-dependent and independent signalling pathways. Cell Microbiol 2005;7:1387-1397. [PubMed: 16153239]

51. Park J, Gores GJ, Patel T. Lipopolysaccharide induces cholangiocyte proliferation via an interleukin-6-mediated activation of p44/p42 mitogen-activated protein kinase. Hepatology 1999;29:1037-1043. [PubMed: 10094943]

52. Jafri M, Donnelly B, McNeal M, Ward R, Tiao G. MAPK signaling contributes to rotaviral-induced cholangiocyte injury and viral replication. Surgery 2007;142:192-201. [PubMed: 17689685]

53. Morland CM, Fear J, McNab G, Joplin R, Adams DH. Promotion of leukocyte transendothelial cell migration by chemokines derived from human biliary epithelial cells in vitro. Proc Assoc Am Physicians 1997;109:372-382. [PubMed: 9220535]

54. Fabris L, Strazzabosco M, Crosby HA, Ballardini G, Hubscher SG, Kelly DA, et al. Characterization and isolation of ductular cells coexpressing neural cell adhesion molecule and Bcl-2 from primary cholangiopathies and ductal plate malformations. Am J Pathol 2000;156:1599-1612. [PubMed: 10793072]

55. Rockey DC, Fouassier L, Chung JJ, Carayon A, Vallee P, Rey C, et al. Cellular localization of endothelin-1 and increased production in liver injury in the rat: potential for autocrine and paracrine effects on stellate cells. Hepatology 1998;27:472-480. [PubMed: 9462646]

56. Lazaridis KN, Strazzabosco M, LaRusso NF. The cholangiopathies: disorders of biliary epithelia. Gastroenterology 2004;127:1565-1577. [PubMed: 15521023]

57. Morita M, Watanabe Y, Akaike T. Inflammatory cytokines up-regulate intercellular adhesion molecule-1 expression on primary cultured mouse hepatocytes and T-lymphocyte adhesion. Hepatology 1994;19:426-431. [PubMed: 7904980]

58. Scholz M, Cinatl J, Blaheta RA, Kornhuber B, Markus BH, Doerr HW. Expression of human leukocyte antigens class I and class II on cultured biliary epithelial cells after cytomegalovirus infection. Tissue Antigens 1997;49:640-643. [PubMed: 9234487]

59. Cruickshank SM, Southgate J, Selby PJ, Trejdosiewicz LK. Expression and cytokine regulation of immune recognition elements by normal human biliary epithelial and established liver cell lines in vitro. J Hepatol 1998;29:550-558. [PubMed: 9824263]

60. Bloom S, Fleming K, Chapman R. Adhesion molecule expression in primary sclerosing cholangitis and primary biliary cirrhosis. Gut 1995;36:604-609. [PubMed: 7537707]

61. Sheen-Chen SM, Eng HL, Cheng YF, Chou FF, Chen WJ. Circulating intercellular adhesion molecule-1 (ICAM-1) in patients with hepatolithiasis. Dig Dis Sci 1996;41:1682-1686. [PubMed: 8769302] 
62. Hsu HY, Chang MH, Ni YH, Huang SF. Cytomegalovirus infection and proinflammatory cytokine activation modulate the surface immune determinant expression and immunogenicity of cultured murine extrahepatic bile duct epithelial cells. Clin Exp Immunol 2001;126:84-91. [PubMed: 11678903]

63. Leon MP, Bassendine MF, Gibbs P, Thick M, Kirby JA. Immunogenicity of biliary epithelium: study of the adhesive interaction with lymphocytes. Gastroenterology 1997;112:968-977. [PubMed: 9041260]

64. Ayres RC, Neuberger JM, Shaw J, Joplin R, Adams DH. Intercellular adhesion molecule-1 and MHC antigens on human intrahepatic bile duct cells: effect of proinflammatory cytokines. Gut 1993;34:1245-1249. [PubMed: 8104850]

65. Saidman SL, Duquesnoy RJ, Zeevi A, Fung JJ, Starzl TE, Demetris AJ. Recognition of major histocompatibility complex antigens on cultured human biliary epithelial cells by alloreactive lymphocytes. Hepatology 1991;13:239-246. [PubMed: 1704868]

66. Iwai Y, Terawaki S, Ikegawa M, Okazaki T, Honjo T. PD-1 inhibits antiviral immunity at the effector phase in the liver. J Exp Med 2003;198:39-50. [PubMed: 12847136]

67. Chen XM, Levine SA, Tietz P, Krueger E, McNiven MA, Jefferson DM, et al. Cryptosporidium parvum is cytopathic for cultured human biliary epithelia via an apoptotic mechanism. Hepatology 1998;28:906-913. [PubMed: 9755224]

68. Adams DH, Afford SC. The role of cholangiocytes in the development of chronic inflammatory liver disease. Front Biosci 2002;7:e276-e285. [PubMed: 12086915]

69. O'Hara SP, Small AJ, Nelson JB, Badley AD, Chen XM, Gores GJ, et al. The human immunodeficiency virus type 1 tat protein enhances Cryptosporidium parvum-induced apoptosis in cholangiocytes via a Fas ligand-dependent mechanism. Infect Immun 2007;75:684-696. [PubMed: 17118988]

70. Chen XM, Gores GJ, Paya CV, LaRusso NF. Cryptosporidium parvum induces apoptosis in biliary epithelia by a Fas/Fas ligand-dependent mechanism. Am J Physiol 1999;277:G599-G608. [PubMed: 10484385]

71. Yang D, Liu ZH, Tewary P, Chen Q, de la Rosa G, Oppenheim JJ. Defensin participation in innate and adaptive immunity. Curr Pharm Des 2007;13:3131-3139. [PubMed: 17979754]

72. Yamaguchi Y, Nagase T, Makita R, Fukuhara S, Tomita T, Tominaga T, et al. Identification of multiple novel epididymis-specific beta-defensin isoforms in humans and mice. J Immunol 2002;169:2516-2523. [PubMed: 12193721]

73. Menendez A, Brett Finlay B. Defensins in the immunology of bacterial infections. Curr Opin Immunol 2007;19:385-391. [PubMed: 17702560]

74. Haller O, Kochs G. Interferon-induced Mx proteins: dynamin-like GTPases with antiviral activity. Traffic 2002;3:710-717. [PubMed: 12230469]

75. Leifeld L, Ramakers J, Schneiders AM, Dumoulin FL, Sterneck M, Müller A, et al. Intrahepatic MxA expression is correlated with interferon-alpha expression in chronic and fulminant hepatitis. J Pathol 2001;194:478-483. [PubMed: 11523057]

76. Huang YH, Chou MH, Du YY, Huang CC, Wu CL, Chen CL, et al. Expression of toll-like receptors and type 1 interferon specific protein MxA in biliary atresia. Lab Invest 2007;87:66-74. [PubMed: 17075576]

77. Al-Masri AN, Flemming P, Rodeck B, Melter M, Leonhardt J, Petersen C. Expression of the interferon-induced Mx proteins in biliary atresia. J Pediatr Surg 2006;41:1139-1143. [PubMed: 16769349]

78. Harada K, Sato Y, Itatsu K, Isse K, Ikeda H, Yasoshima M, et al. Innate immune response to doublestranded RNA in biliary epithelial cells is associated with the pathogenesis of biliary atresia. Hepatology 2007;46:1146-1154. [PubMed: 17661372]

79. Sakisaka S, Gondo K, Yoshitake M, Harada M, Sata M, Kobayashi K, et al. Functional differences between hepatocytes and biliary epithelial cells in handling polymeric immunoglobulin A2 in humans, rats, and guinea pigs. Hepatology 1996;24:398-406. [PubMed: 8690411]

80. Aagaard BD, Heyworth MF, Oesterle AL, Jones AL, Way LW. Intestinal immunisation with Escherichia coli protects rats against Escherichia coli induced cholangitis. Gut 1996;39:136-140. [PubMed: 8881825] 
81. Mostov KE. Transepithelial transport of immunoglobulins. Annu Rev Immunol 1994;12:63-84. [PubMed: 8011293]

82. Alvaro D, Mancino MG, Glaser S, Gaudio E, Marzioni M, Francis H, et al. Proliferating cholangiocytes: a neuroendocrine compartment in the diseased liver. Gastroenterology 2007;132:415-431. [PubMed: 17241889]

83. Rakoff-Nahoum S, Paglino J, Eslami-Varzaneh F, Edberg S, Medzhitov R. Recognition of commensal microflora by toll-like receptors is required for intestinal homeostasis. Cell 2004;118:229-241. [PubMed: 15260992]

84. Shaykhiev R, Behr J, Bals R. Microbial Patterns Signaling via Toll-Like Receptors 2 and 5 Contribute to Epithelial Repair, Growth and Survival. PLoS ONE 2008;3:e1393. [PubMed: 18167552]

85. Tebbutt NC, Giraud AS, Inglese M, Jenkins B, Waring P, Clay FJ, et al. Reciprocal regulation of gastrointestinal homeostasis by SHP2 and STAT-mediated trefoil gene activation in gp130 mutant mice. Nat Med 2002;8:1089-1097. [PubMed: 12219085]

86. Ernst M, Inglese M, Waring P, Campbell IK, Bao S, Clay FJ, et al. Defective gp130-mediated signal transducer and activator of transcription (STAT) signaling results in degenerative joint disease, gastrointestinal ulceration, and failure of uterine implantation. J Exp Med 2001;194:189-203. [PubMed: 11457894]

87. Nozaki I, Lunz JG III, Specht S, Park JI, Giraud AS, Murase N, et al. Regulation and function of trefoil factor family 3 expression in the biliary tree. Am J Pathol 2004;165:1907-1920. [PubMed: 15579435]

88. Hertel SC, Chwieralski CE, Hinz M, Rio MC, Tomasetto C, Hoffmann W. Profiling trefoil factor family (TFF) expression in the mouse: identification of an antisense TFF1-related transcript in the kidney and liver. Peptides 2004;25:755-762. [PubMed: 15177869]

89. Srivatsa G, Giraud AS, Ulaganathan M, Yeomans ND, Dow C, Nicoll AJ. Biliary epithelial trefoil peptide expression is increased in biliary diseases. Histopathology 2002;40:261-268. [PubMed: 11895492]

90. Sasaki M, Ikeda H, Ohira S, Ishikawa A, Nakanuma Y. Expression of trefoil factor family 1, 2, and 3 peptide is augmented in hepatolithiasis. Peptides 2004;25:763-770. [PubMed: 15177870]

91. Anderson JM, Van Itallie CM. Tight junctions and the molecular basis for regulation of paracellular permeability. Am J Physiol Gastrointest Liver Physiol 1995;269:G467-G475.

92. Basuroy S, Sheth P, Kuppuswamy D, Balasubramanian S, Ray RM, Rao RK. Expression of kinaseinactive c-Src delays oxidative stress-induced disassembly and accelerates calcium-mediated reassembly of TJs in the Caco-2 cell monolayer. J Biol Chem 2003;278:11916-11924. [PubMed: 12547828]

93. Cario E, Gerken G, Podolsky DK. Toll-like receptor 2 enhances ZO-1-associated intestinal epithelial barrier integrity via protein kinase C. Gastroenterology 2004;127:224-238. [PubMed: 15236188]

94. Chen XM, Huang BQ, Splinter PL, Cao H, Zhu G, McNiven MA, et al. Cryptosporidium parvum invasion of biliary epithelia requires host cell tyrosine phosphorylation of cortactin via c-Src. Gastroenterology 2003;125:216-228. [PubMed: 12851885]

95. Spirli C, Fabris L, Duner E, Fiorotto R, Ballardini G, Roskams T, et al. Cytokinestimulated nitric oxide production inhibits adenylyl cyclase and cAMP-dependent secretion in cholangiocytes. Gastroenterology 2003;124:737-753. [PubMed: 12612912]

96. Marra F. Chemokines in liver inflammation and fibrosis. Front Biosci 2002;7:d1899-d1914. [PubMed: 12161342]

97. Jaiswal M, LaRusso NF, Gores GJ. Nitric oxide in gastrointestinal epithelial cell carcinogenesis: linking inflammation to oncogenesis. Am J Physiol Gastrointest Liver Physiol 2001;281:G626G634. [PubMed: 11518674]

98. Monick MM, Yarovinsky TO, Powers LS, Butler NS, Carter AB, Gudmundsson G, et al. Respiratory syncytial virus up-regulates TLR4 and sensitizes airway epithelial cells to endotoxin. J Biol Chem 2003;278:53035-53044. [PubMed: 14565959]

99. Schmausser B, Andrulis M, Endrich S, Lee SK, Josenhans C, Müller-Hermelink HK, et al. Expression and subcellular distribution of toll-like receptors TLR4, TLR5 and TLR9 on the gastric epithelium in Helicobacter pylori infection. Clin Exp Immunol 2004;136:521-526. [PubMed: 15147355] 
100. Wang AP, Migita K, Ito M, Takii Y, Daikoku M, Yokoyama T, et al. Hepatic expression of toll-like receptor 4 in primary biliary cirrhosis. J Autoimmun 2005;25:85-91. [PubMed: 16006099]

101. Karrar A, Broomé U, Södergren T, Jaksch M, Bergquist A, Björnstedt M, et al. Biliary epithelial cell antibodies link adaptive and innate immune responses in primary sclerosing cholangitis. Gastroenterology 2007;132:1504-1514. [PubMed: 17408653]

102. Bartel DP. MicroRNAs: genomics, biogenesis, mechanism, and function. Cell 2004;116:281-297. [PubMed: 14744438]

103. Ambros V. The functions of animal microRNAs. Nature 2004;431:350-355. [PubMed: 15372042]

104. Voinnet O. Induction and suppression of RNA silencing: insights from viral infections. Nat Rev Genet 2005;6:206-220. [PubMed: 15703763]

105. Lecellier CH, Dunoyer P, Arar K, Lehmann-Che J, Eyquem S, Himber C, et al. A cellular microRNA mediates antiviral defense in human cells. Science 2005;308:557-560. [PubMed: 15845854]

106. Johnson SM, Grosshans H, Shingara J, Byrom M, Jarvis R, Cheng A, et al. RAS is regulated by the let-7 microRNA family. Cell 2005;120:635-647. [PubMed: 15766527]

107. Lodish HF, Zhou B, Liu G, Chen CZ. Micromanagement of the immune system by microRNAs. Nat Rev Immunol 2008;8:120-130. [PubMed: 18204468]

108. Gantier MP, Sadler AJ, Williams BR. Fine-tuning of the innate immune response by microRNAs. Immunol Cell Biol 2007;85:458-462. [PubMed: 17621315]

109. Taganov KD, Bolding MP, Baltimore D. MicroRNAs and immunity: tiny players in a big field. Immunity 2007;26:133-137. [PubMed: 17307699]

110. Meng F, Henson R, Lang M, Wehbe H, Maheshwari S, Mendell JT, et al. Involvement of human micro-RNA in growth and response to chemotherapy in human cholangiocarcinoma cell lines. Gastroenterology 2006;130:2113-2129. [PubMed: 16762633]

111. Lang T, Mansell A. The negative regulation of Toll-like receptor and associated pathways. Immunol Cell Biol 2007;85:425-434. [PubMed: 17621314]

112. Yasukawa H, Sasaki A, Yoshimura A. Negative regulation of cytokine signaling pathways. Annu Rev Immunol 2000;18:143-164. [PubMed: 10837055]

113. Alexander WS, Starr R, Fenner JE, Scott CL, Handman E, Sprigg NS, et al. SOCS1 is a critical inhibitor of interferon gamma signaling and prevents the potentially fatal neonatal actions of this cytokine. Cell 1999;98:597-608. [PubMed: 10490099]

114. Nakagawa R, Naka T, Tsutsui H, Fujimoto M, Kimura A, Abe T, et al. SOCS-1 participates in negative regulation of LPS responses. Immunity 2002;17:677-687. [PubMed: 12433373]

115. Mansell A, Smith R, Doyle SL, Gray P, Fenner JE, Crack PJ, et al. Suppressor of cytokine signaling 1 negatively regulates Toll-like receptor signaling by mediating Mal degradation. Nat Immunol 2006;7:148-155. [PubMed: 16415872]

116. Yoshimura A, Naka T, Kubo M. SOCS proteins, cytokine signalling and immune regulation. Nat Rev Immunol 2007;7:454-465. [PubMed: 17525754]

117. Isomoto H, Mott JL, Kobayashi S, Werneburg NW, Bronk SF, Haan S, et al. Sustained IL-6/STAT-3 signaling in cholangiocarcinoma cells due to SOCS-3 epigenetic silencing. Gastroenterology 2007;132:384-396. [PubMed: 17241887]

118. O'Connell RM, Taganov KD, Boldin MP, Cheng G, Baltimore D. MicroRNA-155 is induced during the macrophage inflammatory response. Proc Natl Acad Sci USA 2007;104:1604-1609. [PubMed: 17242365]

119. Taganov KD, Boldin MP, Chang KJ, Baltimore D. NF-kappaB-dependent induction of microRNA miR-146, an inhibitor targeted to signaling proteins of innate immune responses. Proc Natl Acad Sci USA 2006;103:12481-12486. [PubMed: 16885212] 


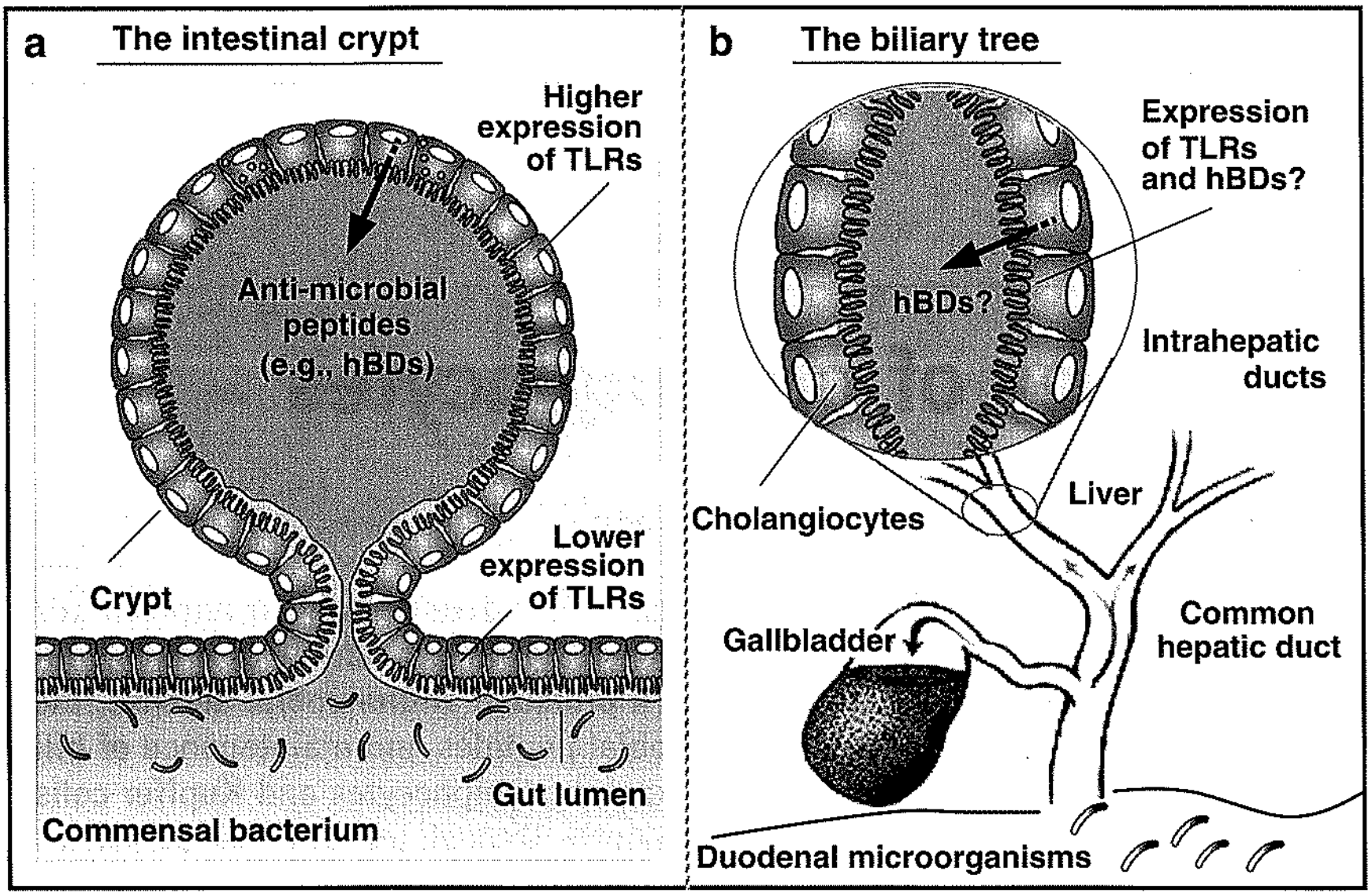

Figure 1.

TLRs and epithelial defenses in the intestine and biliary tract. TLRs are expressed in the intestinal crypts and mediate expression of antimicrobial peptides to keep crypt lumen sterile (a) (modified from Sansonetti ${ }^{24}$ ). Cholangiocytes may defend the biliary lumen using a similar mechanism through TLR-mediated epithelial defense (b). TLRs, Toll-like receptors; hBDs, human $\beta$-defensins. 


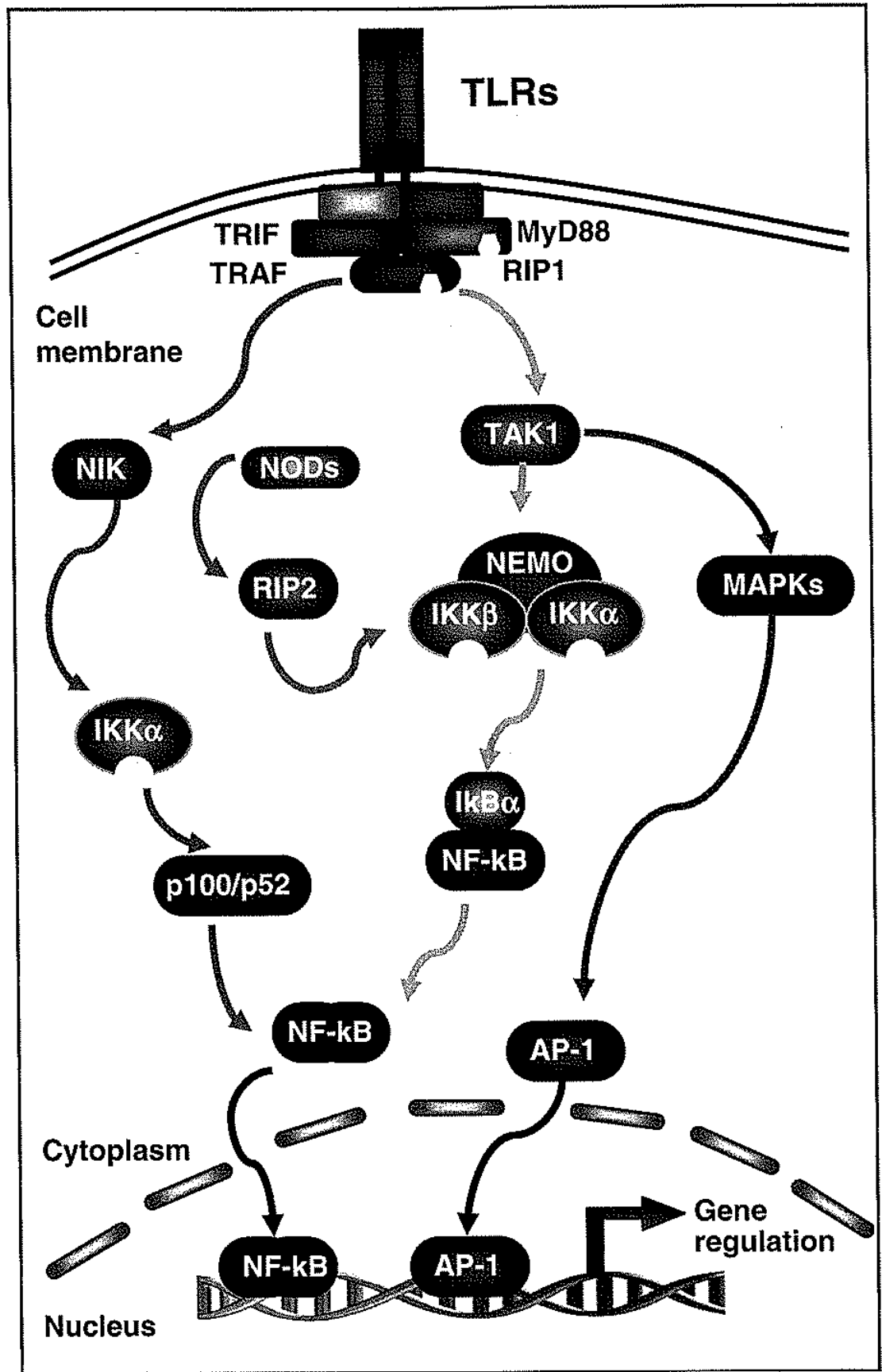

Figure 2.

TLRs/NODs and key intracellular signaling cascades. TLRs recognize distinct pathogen patterns and recruit a set of adaptor proteins to form the signalosome complex. Following receptor ligation and recruitment of receptor adaptor proteins, signaling to IKK proceeds through TRAF/RIP complexes, generally in conjunction with TAK1, leading to canonical NF$\kappa \mathrm{B}$ signaling, or through TRAFs and NIK leading to the noncanonical NF- $\kappa \mathrm{B}$ pathway. NODs recognize intracellular pathogen molecules and recruit RIP2 to activate NF- $\kappa \mathrm{B}$. Activation of IKK results in I $\mathrm{B}$ phosphorylation and degradation in the canonical pathway or p100 processing to $\mathrm{p} 52$ in the noncanonical pathway and consequently, nuclear translocation of phophorylated NF- $\kappa$ B dimers. Those NF- $\kappa$ B dimmers bind to $\kappa B$ DNA elements and regulate 
gene expression. TAK1 can also trigger activation of MAPKs leading to the activator protein-1associated gene regulation. AP-1, activator protein-1; IкB, inhibitory protein kappaB; IKK, inhibitor of kappaB kinase; NF- $\mathrm{KB}$, nuclear-factor $\kappa \mathrm{B}$; NIK, NF-kappaB-inducing kinase; NODs, nucleotide-binding oligomerization domain proteins; RIP, receptor-interacting protein; TAK, transforming growth factor-beta-activated kinase; TLRs, Toll-like receptors; TRAF, TNFR-associated factor; TRIF, Toll/interlukin-1 receptor domain-containing adaptor molecule-1. 


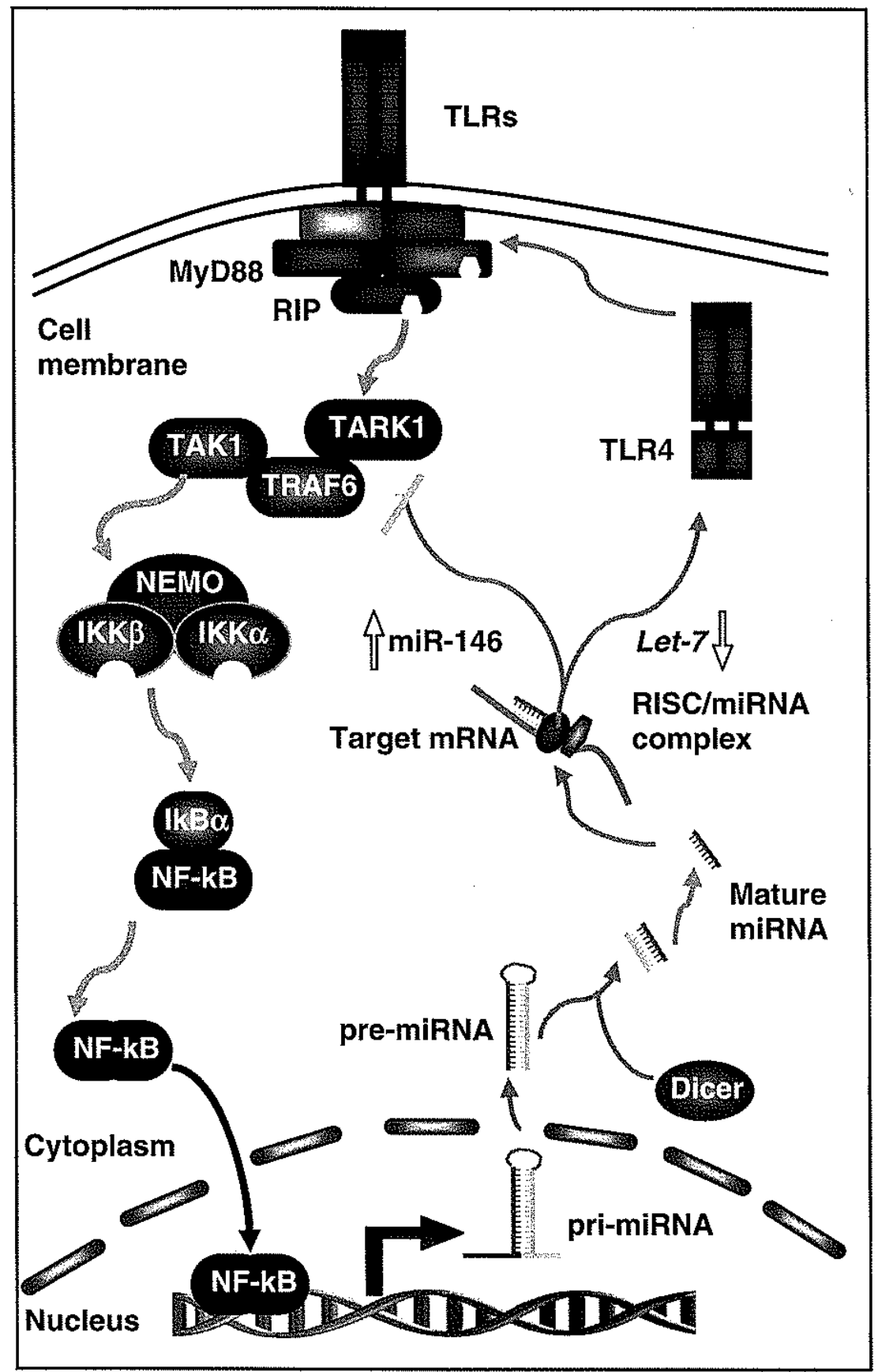

Figure 3.

Feed-back regulation of TLR expression and activation of intracellular signaling cascades through miRNAs. Triggering of TLRs activates downstream NF- $\mathrm{KB}$ signaling leading to subsequent regulation of immune-response genes, including transactivation and transsuppression of miRNA genes. Primary transcripts of miRNAs are processed to form mature miRNAs, which bind to the $3^{\prime} \mathrm{UTR}$ of target mRNAs resulting in post-transcriptional repression. So far, miR-146 has been reported to show an increased expression upon LPS stimulation of TLR4, leading in a reduction in IRAK-1 and TRAF6 expression and attenuation of TLR4 signaling. In contrast, a downregulation of let- 7 has been identified in cholangiocytes following stimulation of TLR4/NF- $\mathrm{kB}$, which results in a relief of translational repression of 
TLR4, leading to an upregulation of TLR4 and enhancement of TLR4-associated epithelial immunity. Thus, the integration of transcriptional regulation of genes with miRNA-mediated post-transcriptional regulation of target mRNAs results in a fine-tuned TLR-associated signaling cascades in cholangiocytes, contributing to the biliary innate immune responses to microbial infection. IкB, inhibitory protein kappaB; IKK, inhibitor of kappaB kinase; IRAK-1, IL-1R-associated kinase; miRNAs, microRNAs; NF- $\mathrm{B}$, nuclear-factor $\mathrm{\kappa B}$; RIP, receptorinteracting protein; RISC, RNA-induced silencing complex; TAK, transforming growth factorbeta-activated kinase; TLR, Toll-like receptor; TRAF6, TNFR-associated factor 6; UTR, untranslated region. 